\title{
Density-dependent effects of an introduced oyster, Crassostrea gigas, on a native intertidal seagrass, Zostera marina
}

\author{
Eric Wagner ${ }^{1, *}$, Brett R. Dumbauld ${ }^{2}$, Sally D. Hacker ${ }^{3}$, Alan C. Trimble ${ }^{1}$, \\ Lorena M. Wisehart ${ }^{3}$, Jennifer L. Ruesink ${ }^{1}$ \\ ${ }^{1}$ Department of Biology, University of Washington, Seattle, Washington 98195, USA \\ ${ }^{2}$ U.S. Department of Agriculture - Agricultural Research Service, Newport, Oregon 97365, USA \\ ${ }^{3}$ Department of Zoology, Oregon State University, Corvallis, Oregon 97331, USA
}

\begin{abstract}
Seagrasses and bivalves co-occur worldwide, and each plays a role in the structure, function, and services of coastal ecosystems. While seagrasses are declining, bivalve aquaculture is expanding, and impacts from culture practices, as opposed to the cultured organisms themselves, need to be distinguished. In 2 experiments, we tested the effects of live Crassostrea gigas, an introduced oyster, on Zostera marina, a native seagrass, in Willapa Bay, Washington. Expt 1 involved adult oyster addition across a large range in density ( 0 to $70 \%$ cover), and also considered the effects of the physical components of an oyster: its shell, and fertilizer mimicking biodeposition. Expt 2 simulated a crop cycle with addition of newly-settled oysters at relevant commercial density $(\leq 20 \%)$, which then grew over 3 yr. In Expt 1, seagrass shoot density and size declined (at least $50 \%$ and at most $40 \%$, respectively) with oyster addition. Steep declines indicating density-dependent space competition occurred at different thresholds after 1 (1.3\% oyster cover), 2 $(12.4 \%)$, and 3 yr $(21.9 \%)$. Live oysters changed sediment characteristics, increasing organic content, silt:sand ratios, and levels of porewater ammonium, but these changes did not affect eelgrass. Nutrient addition did not affect density or growth, although it augmented porewater ammonium. In Expt 2, no significant reductions in density, size, or growth of seagrass occurred. Our results suggest that the effects of introduced oysters on seagrass occur through space competition and can exceed the footprint of the oysters, generating strong impacts above a threshold of $\sim 20 \%$ cover.
\end{abstract}

KEY WORDS: Zostera marina $\cdot$ Crassostrea gigas $\cdot$ Density-dependent effects $\cdot$ Shellfish aquaculture $\cdot$ Disturbance $\cdot$ Recovery

\section{INTRODUCTION}

Seagrasses and bivalves co-occur in coastal marine habitats worldwide (Peterson \& Heck 2001a, Wall et al. 2008), and both taxa can play a strong role in the structure and functioning of ecosystems (e.g. bivalves, Gutierrez et al. 2003, Ruesink et al. 2005; seagrasses, Koch et al. 2009). Global trends show overall declines in seagrasses (Waycott et al. 2009), and also some bivalves, such as reef-forming oysters (Beck et al. 2011), but expansion of bivalve aquaculture continues (Nomura 2009). These trends foster conflict, not only due to different perspectives about the relative economic and ecological value of different marine communities, but also because of scientific uncertainty about the degree of tradeoff between seagrasses and bivalves. In this paper, we explore some of this scientific uncertainty by experimentally planting a widely cultured oyster Crassostrea gigas across a range of densities to determine the response of eelgrass Zostera marina. 
Studies show that disturbances associated with bivalve aquaculture harvest practices can have a negative effect on seagrasses (Tallis et al. 2009, but see Wisehart et al. 2007). However, interactions between bivalves and seagrasses in more 'natural' environments are widely variable. This variation may arise in part due to several different mechanisms by which bivalves could alter environmental conditions for seagrasses: sediment biogeochemistry, structure and space occupation, and water quality.

Oysters may alter sediment biogeochemistry by causing sulfide to accumulate in sediments (Kelly \& Volpe 2007). Sulfide is toxic to seagrasses: photosynthetic activity and growth rates both decrease in the presence of sulfides (Holmer et al. 2005). In contrast, several studies demonstrate that filter-feeding bivalves can enhance seagrass size and growth through direct fertilization, as they eject nutrient-rich feces and pseudofeces (Peterson \& Heck 2001a, Booth \& Heck 2009). These feces and pseudofeces increase the ammonium and/or phosphorus content of sediments. In separate studies, fertilization increased eelgrass shoot size (reviewed in Hughes et al. 2004), although another review found both positive and negative effects of fertilization, frequently depending on the protocol used (Leoni et al. 2008).

From a structural standpoint, oysters add hard substrate to soft-sediment environments and contribute to bathymetric complexity (Gutierrez et al. 2003). Complex structure generally is associated with species diversity and food web architecture, which in the case of mussels within seagrass leads to improved epiphyte control by grazers (Heck et al. 2000). However, the hard surfaces of shells or aquaculture structures could abrade seagrass shoots or catch them in a way that increases desiccation stress at low tide (Schreffler \& Griffen 2000), leading to effects of oysters that extend beyond the physical footprint of their shell. The structural aspects of an oyster persist after its occupant has died and constitute an extended presence.

The effects of oysters on eelgrass via water quality are generally expected to be positive. Oysters remove water-column seston, which increases water clarity and thus could improve seagrass growth by enhancing the amount of light reaching the plants (Nelson et al. 2004); in temperate latitudes, light attenuation with depth is the primary limiting factor for seagrass growth and distribution (Thom et al. 2003).

While there is a general pattern of decreased Zostera marina density and smaller shoot size on cultured oyster beds (Tallis et al. 2009), understanding the mechanisms and magnitude of these decreases requires an experimental approach. In this paper, we report on the effects of an introduced bivalve, the Pacific oyster Crassostrea gigas, on a native seagrass, eelgrass $Z$. marina, across densities in small-scale field experiments. We manipulated the structural and biogeochemical aspects of oysters in a crossed experimental design, and expected shell to reduce eelgrass density (due to space competition) and shoot size (due to leaf abrasion), but nutrients to increase size or growth (due to fertilization). Separately, we added oysters across a range of densities. A key consideration for the coexistence of bivalves and eelgrass involves the functional shape of potential tradeoffs (Koch et al. 2009); specifically, thresholds beyond which eelgrass responds more strongly than expected from the effects of displacement and space competition with bivalves alone.

\section{MATERIALS AND METHODS}

\section{Sites and species}

The study took place in Willapa Bay, a partially mixed estuary in southwest Washington State, USA. The second largest estuary along the open west coast of the USA, Willapa Bay covers 35000 ha at mean high water but has a large tidal prism $(60 \%$ of the area exposed at low tide) (Borde et al. 2003), and is subject to strong seasonal variations in oceanic input due to wind-driven upwelling and downwelling events, as well as periodic freshwater influxes from the Columbia River plume (Hickey \& Banas 2003). It is a major site of shellfish aquaculture production, primarily oysters and clams (Ruesink et al. 2006, Dumbauld et al. 2009). Crassostrea gigas was introduced from Japan in 1928 and is currently cultivated on-bottom (averaging $20 \%$ cover) or in clusters on longlines suspended above the tideflats; C. gigas also has established reefs where it recruits naturally. Nearly $10 \%$ of the USA's total oyster harvest comes from Willapa Bay (Ruesink et al. 2006), and about $21 \%$ of the bay's intertidal area is farmed and managed for oysters (Dumbauld et al. 2009). The bay also contains extensive beds of Zostera marina (3400 ha) at elevations of -1.0 to $+0.6 \mathrm{~m}$ relative to mean lower low water (MLLW) (Ruesink et al. 2010). Shoot size tends to be large and density accordingly low ( 100 shoots $\mathrm{m}^{-2}$ ) (Thom et al. 2003, Ruesink et al. 2010).

All experiments were within the Washington State Oyster Reserves, which are currently managed to promote natural recruitment of Crassostrea gigas for 
harvest, but were established more than a century ago to maintain stocks of the native oyster, Ostrea lurida, and therefore include lower tidal elevations suitable for eelgrass (Dumbauld et al. 2011).

\section{Expt 1: parsed oyster effects}

The first experiment had 2 goals: (1) to test the effects of different densities of live Crassostrea gigas on Zostera marina densities and growth rates, and (2) to distinguish the effects of oyster structure (i.e. their shells) and nutrient additions (i.e. ejection of feces and pseudofeces). We selected 2 sites, Mill Channel $\left(46.504^{\circ} \mathrm{N}, 124.008^{\circ} \mathrm{W}\right)$ and Peterson Station $\left(46.482^{\circ} \mathrm{N}, 123.997^{\circ} \mathrm{W}\right)$, each with extensive $Z$. marina beds and patches of naturally-recruited $C$. gigas. Both sites are close to the middle of the bay, about $14 \mathrm{~km}$ from the estuary mouth, and approximately $3 \mathrm{~km}$ away from each other. We set up a $6 \times$ 5 arrayed grid of plots at approximately MLLW at Peterson Station, and $0.3 \mathrm{~m}$ above MLLW at Mill Channel. Each plot measured $2 \times 2 \mathrm{~m}$, and was separated from adjacent plots by a $3 \mathrm{~m}$ corridor. Five replicate plots were designated randomly among 6 treatments: eelgrass control, 30\% live oyster (lowdensity), $70 \%$ live oyster (high-density), $70 \%$ empty shell, nutrients, and $70 \%$ empty shell + nutrients. For the eelgrass control treatment, the plot was left unchanged. We spread small clusters of live $C$. gigas, collected either onsite or from nearby beds, across approximately $30 \%$ of the plot for the lowdensity treatment and approximately $70 \%$ of the plot for the high-density treatment. Clusters were generally made up of 10 or fewer attached mediumsized adult oysters; each adult was approximately 10 to $15 \mathrm{~cm}$ in length. For empty shell and empty shell + nutrient treatments, approximately $70 \%$ of the plot was covered with valves of shucked oysters. Valves were spread across the plots singly, and unattached, meaning that there was less vertical structure than in the live oyster treatments. Although there was some movement due to hydrodynamic forces, treatment separation was maintained throughout the experiment. For the nutrients and empty shell + nutrient plots, we scattered $\sim 59 \mathrm{ml}(1 / 4$ cup) of Scott's Osmocote ${ }^{\circledR}$ controlled-release fertilizer. Each bead of fertilizer releases nitrogen, phosphorous and potassium over the course of several weeks; the exact duration depends on ambient water temperature. Treatments were established in May and June 2004, and fertilizer was replaced at 3 to 4 mo intervals through 2005.

\section{Response variables}

Eelgrass density and percentage oyster shell cover

We surveyed all plots using $0.25 \mathrm{~m}^{2}$ quadrats placed in the plot center to determine density of Zostera marina shoots. We estimated percent cover of Crassostrea gigas, including empty oyster shell, to the nearest $5 \%$. Density measurements were taken in July 2004 (to account for pre-treatment densities), June 2005, July 2006, and August 2007.

\section{Eelgrass shoot size and growth}

Our metrics of Zostera marina performance included shoot size and, by standardizing leaf extension to initial leaf length, size-corrected growth. We used a leaf-marking technique, making 2 needle holes near the top of the leaf sheath, to measure above-ground leaf extension (Short \& Duarte 2001). All above-ground tissue from each marked shoot was collected 3 to $4 \mathrm{~d}$ later. Non-growing leaves were discarded, as were older leaves that had $<15 \mathrm{~mm}$ growth, and damaged shoots. We measured the lengths of new (reference to mark) and original portions (mark to leaf tip) of each growing leaf to the nearest $\mathrm{mm}$. Original and new material beyond the leaf sheath from each shoot was dried $\left(60^{\circ} \mathrm{C}\right.$ to constant biomass) and weighed (to the nearest $0.1 \mathrm{mg}$ ) separately. We determined plant size as (1) maximum leaf length (length of longest leaf above the sheath, which represents 75 to $80 \%$ of maximum plant length; J. L. Ruesink unpubl. data), and (2) sizecorrected growth (new length per original length of growing leaves above the sheath per day). Growth measurements were taken in May 2005 and July 2006.

\section{Sediment grain size and organic content}

We measured silt:sand ratio and organic content of sediments in the experimental plots in May 2005 and July 2006. Cores of surface sediment (up to $3 \mathrm{~cm}$ ) were taken from each plot in Mill Channel and Peterson Station and then dried. One portion was ashed for $3 \mathrm{~h}$ at $500^{\circ} \mathrm{C}$ to determine organic content through loss on ignition. Sediment was sieved (Ro-tap RX-29, W.S. Tyler) through $0.063 \mathrm{~mm}$ mesh to separate sand from silt; this sediment was previously ashed in 2005 but not 2006. 
Porewater nutrients

Porewater is contained interstitially in submerged sediments. We obtained porewater using custom piezometers that were deployed in each plot at a depth of about $5 \mathrm{~cm}$, surrounded by beach sand. The sand was necessary to prevent fine sediments from entering the piezometers. Each piezometer consisted of a $2.5 \mathrm{~cm}$ long piece of PVC pipe, $5 \mathrm{~cm}$ in diameter, with the ends covered by $0.5 \mathrm{~mm}$ mesh. We inserted a flexible tube through the pipe, which extended above the sediment surface so we could withdraw porewater with a syringe. We left the filter in the plot for at least $2 \mathrm{~d}$ prior to returning. Extracted porewater was kept cool and dark until processing less than $6 \mathrm{~h}$ later. Samples were filtered $(0.43 \mu \mathrm{m})$, and $10 \mathrm{ml}$ was diluted with $40 \mathrm{ml}$ of distilled, deionzed water and frozen until analysis. Samples were processed at the Marine Chemistry Laboratory at the University of Washington, where ammonium was measured using a modification of the Slawyk \& MacIsaac (1972) procedure. Porewater was extracted in May 2005 at Mill Channel from an array of plots where eelgrass was removed in 2004, but which otherwise received identical oyster, shell, and nutrient treatments as those described above.

\section{Expt 2: crop cycle}

A similar experiment was set up to record responses of eelgrass to live oyster addition simulating typical aquaculture densities and procedures, in which shell with juvenile oysters (cultch) is distributed on the sediment, and the oysters increase in size over several years prior to harvest. In June 2002, we set up blocks of nine $5 \times 5 \mathrm{~m}$ plots near MLLW at Nemah $\left(46.54841^{\circ} \mathrm{N}, 123.93487^{\circ} \mathrm{W}\right)$ and Jensen Point $\left(46.47022^{\circ} \mathrm{N}, 124.00455^{\circ} \mathrm{W}\right)$ in Willapa Bay. At each site, 1 block was established in an undisturbed eelgrass meadow and another in a meadow that had been disturbed by passes of a harvest dredge the previous March. Because past disturbance was not of interest in this study, we considered the experiment to have 4 blocks. In each block, 3 replicate plots were assigned to each of the following 3 treatments: no cultch, $10 \%$ cultch cover per plot (low), or $20 \%$ cultch cover per plot (high); these matched target levels (247-741 bags of cultch ha ${ }^{-1}$ ) that growers typically use for on-bottom oyster culture. Storm events dislodged oysters from the plots during winter, so oysters were moved back into treatments in April 2003, and again in April 2004 until the plots again contained clusters of oysters at about similar density ( $10 \%$ or $20 \%$ cover, depending on treatment). Measured responses to the treatments included eelgrass density, size and growth (as described above). Density was measured over 3 yr: August 2003, August 2004, and June 2005. Growth and size were measured as in Expt 1 in July 2003.

\section{Statistical analyses}

We compared percentage oyster shell cover (arcsine-square root transformed) and eelgrass density $(\log ($ shoots +1$))$ across treatments using linear mixed-effects models. In Expt 1, treatments of 3 live oyster densities were recorded over $3 \mathrm{yr}$; thus, treatment, year, and their interaction were fixed effects, and site and plot (because plots were sampled over multiple years) were random effects. The empty shell and nutrient component of Expt 1 involved 2 treatments in a crossed design recorded after $1 \mathrm{yr}$, after which oysters recruited naturally to the empty shell and we stopped adding nutrients. Thus +/- empty shell, +/- nutrients, and their interaction were fixed effects, and site was a random effect. The control treatment was used in both groups.

For individual-level traits of Zostera marina in Expt 1, we compared size and size-corrected growth across treatments with linear mixed-effects models. Separating the 2 groups, treatment was a fixed factor, and site and plot (for the live oyster group, in which measurements were taken in 2005 and 2006) were random factors.

For sediment characteristics in Expt 1, dependent variables were silt:sand ratio and the proportion of organic material, with treatment as a fixed factor and year, site, and plot as random factors; the analysis of porewater nutrients had no random effect since data were available from only 1 time and site.

Because percentage live oyster shell cover departed from initial treatments over 3 yr in Expt 1, we took the opportunity to measure effects of live oysters as a continuous variable, and examined the shape of the relationship between percentage live oyster shell cover and eelgrass shoot density by year for all treatments - that is, whether it was linear or non-linear with an abrupt threshold. We compared the log-likelihoods of 2 cases of a Poisson power-exponential function:

$$
f(x)=a e^{-b x^{\theta}}
$$

where $x$ is percentage live oyster shell cover, $a$ and $b$ are the scale parameters, and $\theta$ is a shape parameter. 
The power-exponential has a flexible shape that may include an inflection point or 'threshold' $(\theta>1)$ or not $(\theta \leq 1)$. Since density is a non-negative integer (i.e. a count of shoots), we assumed a Poisson loglikelihood $(L)$, given by the equation:

$$
L=\sum_{i=1}^{n} y_{i} \log \left(\hat{f}\left(x_{i}\right)\right)-\hat{f}\left(x_{i}\right)-\log \left(y_{i} !\right)
$$

where $n$ is the number of observations, $\hat{f}\left(x_{i}\right)$ is the fitted mean given by Eq. (1) and $y$ is the response variable. We estimated parameters for the powerexponential function by minimizing the negative loglikelihood function using the Nelder-Mead algorithm (Nelder \& Mead 1965). Parameters were log-transformed to constrain the estimates to positive values and to improve asymptotic confidence intervals and p-values. As a reference non-threshold model, we used a special case of the Poisson power-exponential model with $\theta=1$; that is, exponential decline at a constant rate with increasing percentage live oyster shell cover. We then tested whether there was evidence for an inflection point $(\theta>1)$, by comparing the Akaike Information Criterion (AIC) values for the full and reduced models (Burnham \& Anderson 2002). We calculated AIC values corrected for small sample sizes $\left(\mathrm{AIC}_{\mathrm{C}}\right)$, and considered models for which the difference of $\mathrm{AIC}_{\mathrm{C}}\left(\Delta \mathrm{AIC}_{\mathrm{C}}\right)$ was less than 2.0 to have equivalent explanatory power.

To obtain point estimates and confidence intervals (via likelihood profile or the delta method) of the actual inflection point in the oyster-eelgrass relationship we set the second partial derivative equal to zero and solved for $x^{*}$. For the power-exponential model, this value is

$$
x^{*}=\left(\frac{\theta-1}{b \theta}\right)^{1 / \theta}
$$

which is the percentage live oyster shell cover at which eelgrass declines most rapidly -in other words, the threshold for a large effect. This value is biologically feasible (that is, positive) when $\theta>1$.

In Expt 2, we compared percentage oyster cover (arcsine-square root transformed) and eelgrass shoot density (untransformed because residuals were well distributed) across cultch addition treatments. Treatment, year, and their interaction were fixed effects, and year was a continuous variable to account for oyster growth over the course of the experiment. Block and plot were random effects, with plot nested in block.

For individual-level traits of Zostera marina in Expt 2, treatment was a fixed factor, while block was a random factor. Shoots per plot were averaged before analysis. Variables for the growth metrics met assumptions of normality and homogeneity of variance as determined by a Fligner-Killeen test. All analyses were performed in R (R Development Core Team 2009).

\section{RESULTS}

\section{Expt 1: parsed oyster effects}

Live oyster addition

The addition of live adult oysters occurred at 2 levels, resulting in average oyster cover of $44 \%$ (high), $26 \%$ (low), and 2\% (control) over the 3 yr experiment. Treatment had a significant effect on oyster cover, but time did not (treatment: $F_{2,26}=26.03, \mathrm{p}<$ 0.0001 ; time: $F_{2,54}=0.09, \mathrm{p}=0.91$; treatment $\times$ time: $F_{4,54}=0.44, \mathrm{p}=0.78$ ) (Fig. 1A). In response to these oyster additions, eelgrass density declined by $64 \%$ (high) and $50 \%$ (low) relative to controls (treatment: $F_{2,26}=34.12, \mathrm{p}<0.0001$; time: $F_{2,54}=6.16, \mathrm{p}=0.004$; treatment $\times$ time: $\left.F_{4,54}=1.51, \mathrm{p}=0.2\right)($ Fig. $1 \mathrm{~B})$.
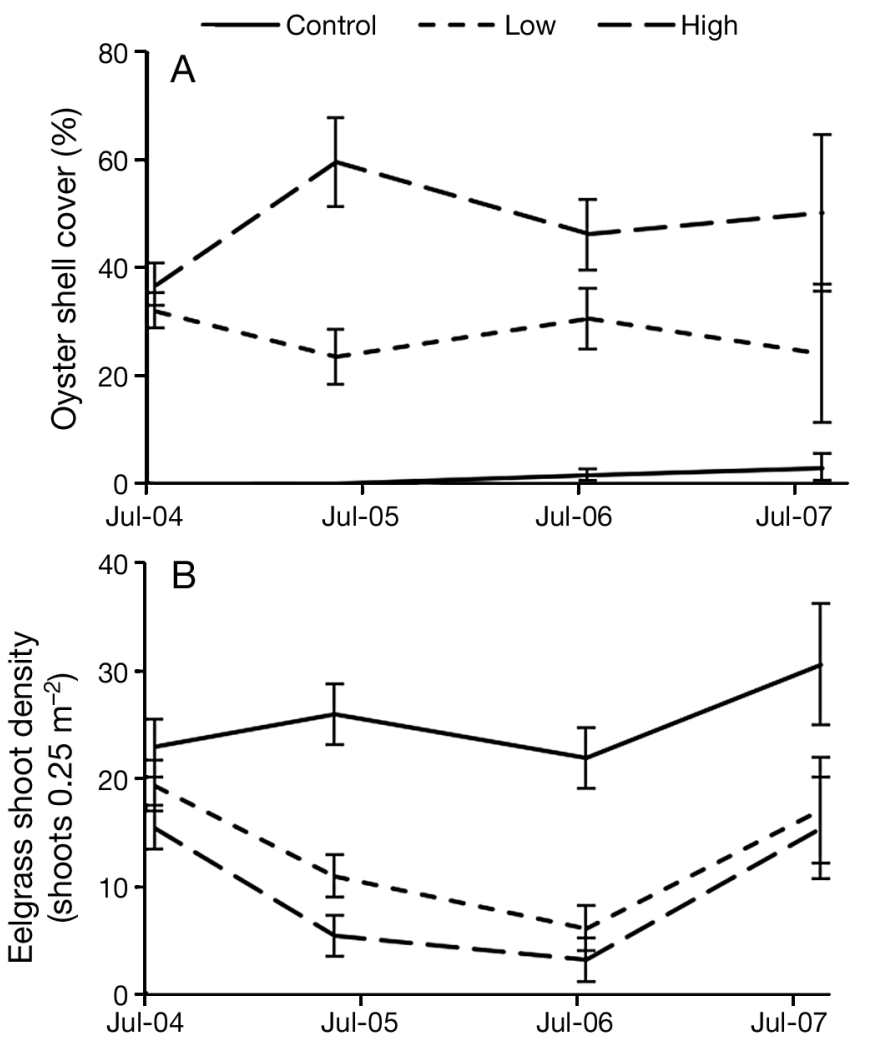

Fig. 1. Results of live oyster addition experiment. (A) Percentage live Crassostrea gigas shell cover from July 2004 (included here to show pre-treatment levels, but not included in analysis) through August 2007; (B) Zostera marina shoot density from July 2004 through August 2007. Error bars are \pm SE 
Live oysters reduced eelgrass size, as indicated by a decline in leaf length of 12 and $22 \%$ in lowand high-density oyster plots, respectively, compared to eelgrass controls $\left(F_{2,53}=8.84, \mathrm{p}=0.0005\right)$ (Fig. 2A). However, size-corrected growth was similar across treatments $\left(F_{2,53}=2.02, \mathrm{p}=0.14\right)$ (Fig. 2B). Live oyster addition increased ammonium concentration in porewater $\left(F_{2,12}=91.55, \mathrm{p}<\right.$ 0.0001, Tukey's HSD: high > low > control) (Fig. 2C), as well as organic content $\left(F_{2,44}=11.93\right.$, $\mathrm{p}<0.0001$, Tukey HSD: high $>$ low $>$ control) (Fig. 2D) and the silt:sand ratio $\left(F_{2,44}=5.71, \mathrm{p}=\right.$ 0.006, Tukey HSD: high > low > control) (Fig. 2E) in surrounding sediments.

\section{Shell and nutrient addition}

When empty shells and nutrients were added to plots in a crossed design, the effects of shells were visible even when their cover was $20 \%$ in 2005 in the shell and shell + nutrient treatments (Table 1, Fig. 3A). Eelgrass shoot density declined with the addition of empty shells, but did not change with nutrient addition (Table 1, Fig. 3B). Density was reduced $>60 \%$ by empty shell and nearly $50 \%$ in the shell + nutrient treatments (Fig. 3B), and leaf length was 30\% smaller in shell + nutrients plots (Table 1, Fig. 3C). Size-corrected growth was not affected by either shell or nutrients (Table 1, Fig. 3D).

Porewater ammonium increased in the fertilized plots: the shell + nutrient treatment had porewater ammonium concentrations that were significantly lower than the nutrient treatment, but greater than the control and shell treatments, but the addition of shells without nutrients had no effect on ammonium concentrations (Tukey's HSD: nutrients > shell + nutrients $>$ shell $>$ control) (Table 1, Fig. 3E). Sediment characteristics were unaffected by either shell or nutrient additions (Table 1, Fig. 3F, G).
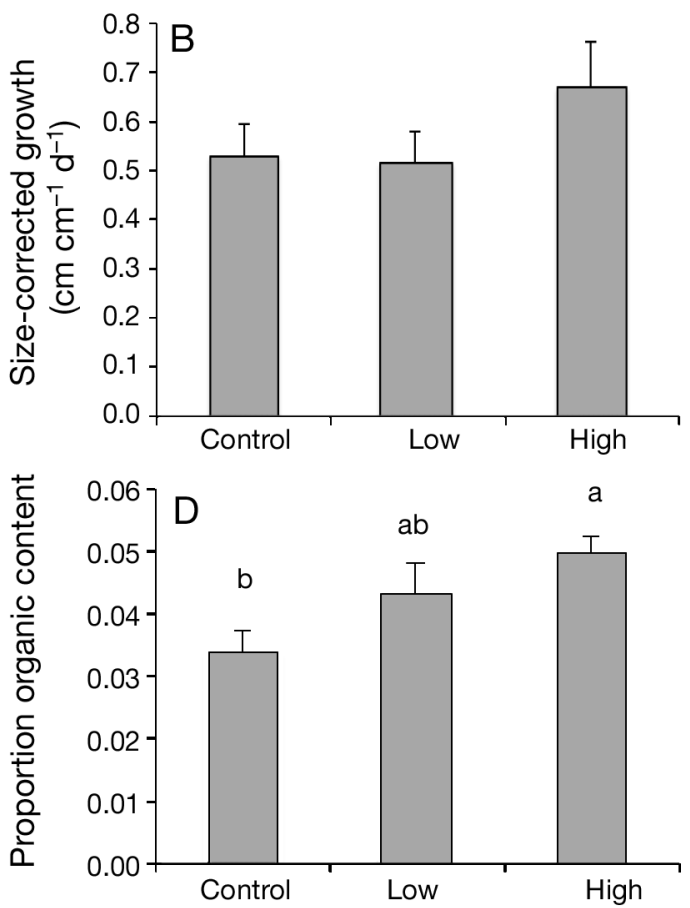

Fig. 2. Results of live oyster addition (low/high cover) experiment. (A) Zostera marina maximum shoot size; (B) Z. marina size-corrected growth rates; (C) porewater ammonium concentrations; (D) proportion of organic content in sediments; (E) silt:sand ratios in sediments. Letters $\mathrm{a}-\mathrm{C}$ indicate significant differences among treatments. Error bars show SE 

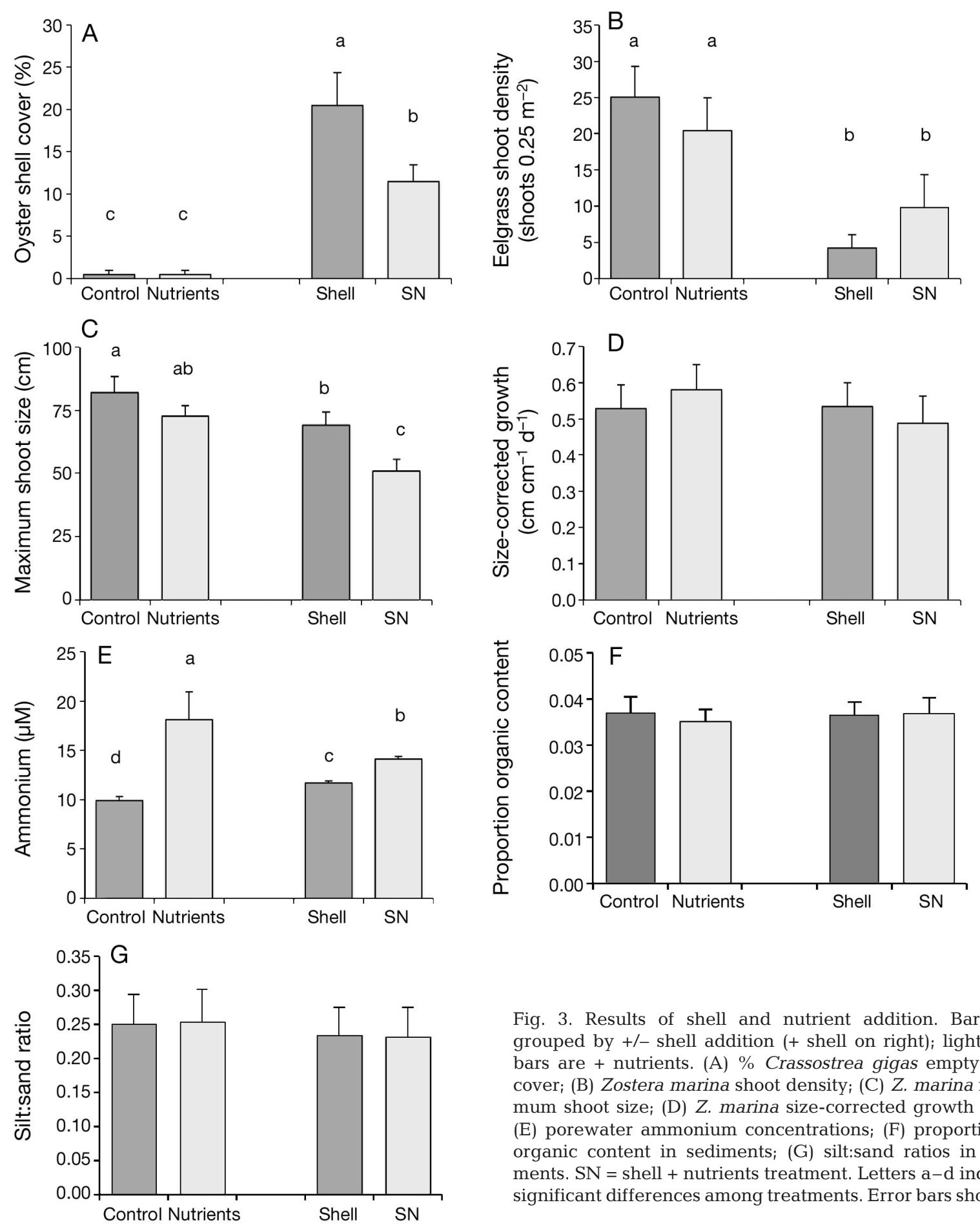

Fig. 3. Results of shell and nutrient addition. Bars are grouped by $+/-$ shell addition (+ shell on right); light gray bars are + nutrients. (A) \% Crassostrea gigas empty shell cover; (B) Zostera marina shoot density; (C) Z. marina maximum shoot size; (D) Z. marina size-corrected growth rates; (E) porewater ammonium concentrations; (F) proportion of organic content in sediments; (G) silt:sand ratios in sediments. $\mathrm{SN}=$ shell + nutrients treatment. Letters a-d indicate significant differences among treatments. Error bars show SE

Density-dependent response of eelgrass shoot density to \% live oyster shell cover

Following implementation of the experimental treatments, eelgrass shoot density declined significantly with increasing percentage live oyster shell cover for some of the years studied (Table 2, Fig. 4).

In 2004, immediately following placement of live oysters, there was no significant relationship between eelgrass shoot density and percentage live oyster shell cover (Table 2, Fig. 4A). In 2005, after the treatments had been in place for $1 \mathrm{yr}$, both the reference and power-exponential models had equivalent explanatory power, with eelgrass shoot density 
Table 1. Results of linear mixed-effects models on eelgrass growth metrics in shell or nutrient treatment groups in Expt 1. Measurements were made in 2005. 'Size' is the longest leaf length above the sheath, and 'Size-corrected growth rate' is new length per original length of growing leaves above the sheath per day. Significant p-values of fixed effects are in bold

\begin{tabular}{|lccc|}
\hline Response variable & Fixed effect & $F$ & $\mathrm{p}$ \\
\hline Percentage oyster & Nutrient & 3.01 & 0.07 \\
shell cover & Shell & 48.86 & $<\mathbf{0 . 0 0 0 1}$ \\
& Nutrient $\times$ shell & 0.06 & 0.67 \\
Eelgrass & Nutrient & 0.01 & 0.91 \\
shoot density & Shell & 17.46 & $\mathbf{0 . 0 0 0 2}$ \\
& Nutrient $\times$ shell & 1.87 & 0.18 \\
Size-corrected & Nutrient & 0.02 & 0.87 \\
growth rate & Shell & 0.37 & 0.55 \\
& Nutrient $\times$ shell & 0.49 & 0.48 \\
Size & Nutrient & 2.17 & 0.69 \\
& Shell & 5.07 & $\mathbf{0 . 0 3}$ \\
Silt:sand ratio & Nutrient $\times$ shell & 0.21 & 0.65 \\
& Nutrient & 0.004 & 0.98 \\
Proportion & Shell & 0.18 & 0.67 \\
organic content & Nutrient $\times$ shell & 0.0001 & 0.95 \\
& Nutrient & 0.07 & 0.79 \\
Porewater & Shell & 0.04 & 0.85 \\
ammonium & Nutrient $\times$ shell & 0.004 & 0.95 \\
& Nutrient & 16.48 & $\mathbf{0 . 0 0 1}$ \\
& Shell & 0.71 & 0.42 \\
& Nutrient $\times$ shell & 5.08 & $\mathbf{0 . 0 4}$ \\
\hline
\end{tabular}

there was a Treatment $\times$ Time interaction (Treatment: $F_{2,30}=372.56, \mathrm{p}<0.0001$, Time: $F_{1,69}=44.99, \mathrm{p}$ $<0.0001$, Time $\times$ Treatment: $\left.F_{2,69}=4.88, \mathrm{p}=0.01\right)$ (Fig. 5A). Treatment separation was preserved throughout the study; the interaction may have been due to the fact that, in the control treatment, oyster cover was effectively held at zero, while in the lowand high-density treatments oyster cover increased by $>40 \%$ by 2005 .

Only time had a significant effect on Zostera marina shoot densities (Treatment: $F_{2,30}=2.5, \mathrm{p}=0.1$; Time: $F_{1,69}=8.01, \mathrm{p}=0.006$; Time $\times$ Treatment: $F_{2,69}=0.4, \mathrm{p}=0.67$ ) (Fig. $5 \mathrm{~B}$ ), with controls declining $\sim 50 \%$ and low- and high-density treatments declining by $\sim 20 \% 2$ yr after treatments were established, although post-hoc tests showed that only the control declines were significant. Note that although they did not differ statistically, the shoot densities were higher in the high-density cultch treatment than in the low-density treatment.

On an individual shoot basis, eelgrass was not significantly affected by differing oyster densities: there were no treatment effects for size or size-corrected growth (size: $F_{2,30}=0.09, \mathrm{p}=0.91$; growth: $F_{2,30}=$ $2.14, \mathrm{p}=0.14)$. declining to half of its control value when percentage live oyster shell cover was greater than $1.3 \%$ (Table 2, Fig. 4B). In 2006, the power-exponential model better explained observed patterns. Eelgrass had started to recover to pre-treatment levels in areas of lower percentage live oyster shell cover, but above a threshold of $12.4 \%$, densities were $<5$ shoots $0.25 \mathrm{~m}^{-2}$ (Table 2, Fig. 4C). By 2007 , after $3 \mathrm{yr}$, there was still a negative relationship between eelgrass shoot density and percentage live oyster shell cover. The power-exponential model had greater explanatory power, but the threshold of percentage live oyster shell cover at which eelgrass declined had increased to $21.3 \%$ (Table 2, Fig. 4D).

\section{Expt 2: crop cycle}

Both treatment and time had an effect on oyster cover in Expt 2, and
Table 2. Summary of $\Delta \mathrm{AIC}_{\mathrm{c}}$ comparison between power-exponential (Power) and reference (Ref) models. Estimates are given with $95 \%$ confidence intervals in parentheses. NegLL is negative log-likelihood. Threshold is the percentage live oyster shell cover at which point eelgrass shoot density declines precipitously according to the favored model. The model favored by $\Delta \mathrm{AIC}_{\mathrm{c}}$ for a given year is shown in bold. For 2004 and 2005, models have equivalent explanatory power. For 2006 and 2007, the power-exponential model is favored

\begin{tabular}{|c|c|c|c|c|c|c|c|}
\hline Year & Model & $\mathrm{N}$ & $\begin{array}{l}\text { Para- } \\
\text { meters }\end{array}$ & $\begin{array}{l}\text { Estimates } \\
(95 \% \text { CI })\end{array}$ & NegLL & $\Delta \mathrm{AIC}_{\mathrm{c}}$ & $\begin{array}{c}\text { Threshold } \\
(\%)\end{array}$ \\
\hline \multirow[t]{5}{*}{2004} & Power & 30 & a & 22.75 (19.95-25.8) & 114.2 & 0 & - \\
\hline & & & $b$ & $0.01(-27.98-27.96)$ & & & \\
\hline & & & $\theta$ & $0.92(0-5.11)$ & & & \\
\hline & Ref & 30 & a & $22.7(20.62-24.78)$ & 114.2 & 0 & \\
\hline & & & $b$ & $0.01(0.003-0.12)$ & & & \\
\hline \multirow[t]{5}{*}{2005} & Power & 30 & $a$ & $24.7(21.75-27.9)$ & 110.03 & 1.07 & 1.3 \\
\hline & & & $b$ & $0.19(0.09-0.34)$ & & & \\
\hline & & & $\theta$ & $0.82(0.62-1.07)$ & & & \\
\hline & Ref & 30 & $a$ & $23.85(21.16-26.77)$ & 111.1 & 0 & \\
\hline & & & $b$ & $0.11(0.09-0.14)$ & & & \\
\hline \multirow[t]{5}{*}{2006} & Power & 30 & $a$ & 21.45 (18.51-24.8) & 81.9 & 0 & 12.4 \\
\hline & & & $b$ & $0.01(0.002-0.03)$ & & & \\
\hline & & & $\theta$ & $1.53(1.18-1.98)$ & & & \\
\hline & Ref & 30 & a & $23.9(20.88-27.23)$ & 87.1 & 5.2 & \\
\hline & & & $b$ & $0.06(0.05-0.07)$ & & & \\
\hline \multirow[t]{5}{*}{2007} & Power & 30 & $a$ & $28.4(25.76-30.83)$ & 161.6 & 0 & 21.9 \\
\hline & & & $b$ & $0.001(0.00001-0.003)$ & & & \\
\hline & & & $\theta$ & $1.88(1.31-2.61)$ & & & \\
\hline & Ref & 30 & $a$ & $30.49(28.03-33.1)$ & 168.3 & 6.7 & \\
\hline & & & $b$ & $0.03(0.02-0.04)$ & & & \\
\hline
\end{tabular}




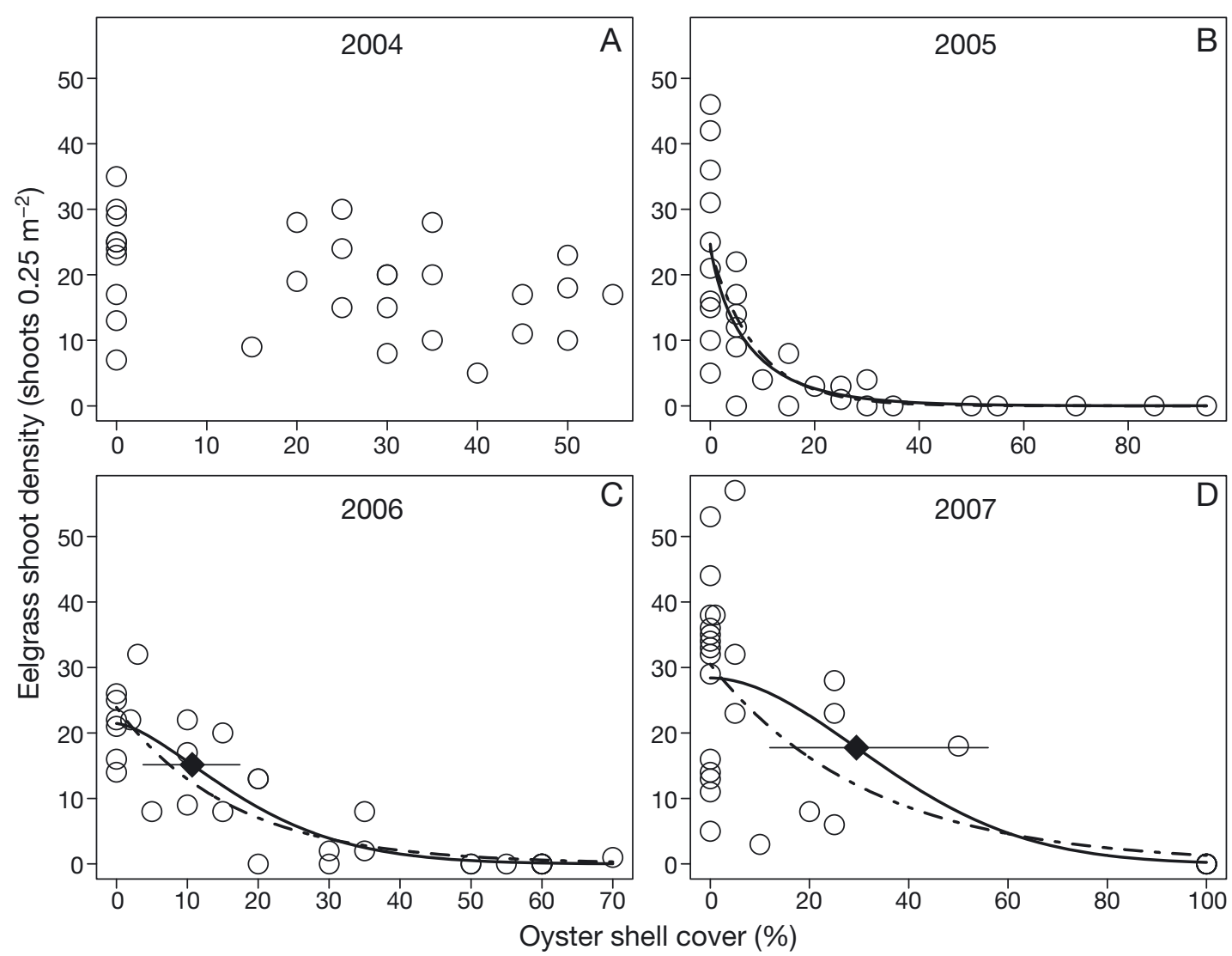

Fig. 4. Comparison of explanatory power of power-exponential and reference models for the density-dependent relationship between the percentage of live Crassostrea gigas shell cover and eelgrass shoot density in the live oyster addition experiment. Solid lines represent power-exponential fit; dashed lines, the reference fit. For 2005, both models have equal explanatory power. For both 2006 and 2007, the power-exponential has greater explanatory power. Black diamonds are defined inflection points; error bars show $95 \%$ confidence intervals. 2004 is provided as a pre-treatment comparison

\section{DISCUSSION}

Three mechanisms are proposed to govern effects of oysters on seagrass biomass and yield: physical structure, nutrient availability, and water clarity. Of these 3, structure emerged as a likely factor underlying space competition in our experiments. Eelgrass responded to the presence of oysters (both live adults and empty shells) by reducing shoot density and size (Fig. 2). In contrast, the nutrient addition treatments, which nearly doubled porewater ammonium concentrations over controls, generated no detectable response in size or density of eelgrass (Figs. $2 \& 3$ ). Size-corrected growth was unaffected by any of these treatments. The alteration of nutrient availability that we achieved by fertilization was similar to that produced by high densities of oysters, but based on the lack of response of eelgrass to direct fertilization, nutrient excretion produced by oysters, at least at this spatial scale, does not appear to affect eelgrass in Willapa Bay. In contrast, seagrasses in other systems, where nutrients may have been limiting, responded positively to nutrients recycled from bivalves (Peterson \& Heck 2001a,b), but negatively to high rates of biodeposition and sulfide accumulation (Vinther \& Holmer 2008); and, in one study, seagrass production per area peaked at intermediate oyster density (Booth \& Heck 2009).

Sediment and nutrient changes that we observed indicate that live oysters are effective ecosystem engineers in this system (Figs. 2D,E \& 3D,E). At high densities, they increased organic content by $22 \%$ and porewater ammonium by $66 \%$ compared to surrounding eelgrass. These engineering effects emerged in our small-scale experiments even though they were not evident in a previous across-habitat observational study in Willapa Bay (Richardson et al. 2008).

We did not collect data that would allow us to evaluate oysters' impact on water column seston or water 

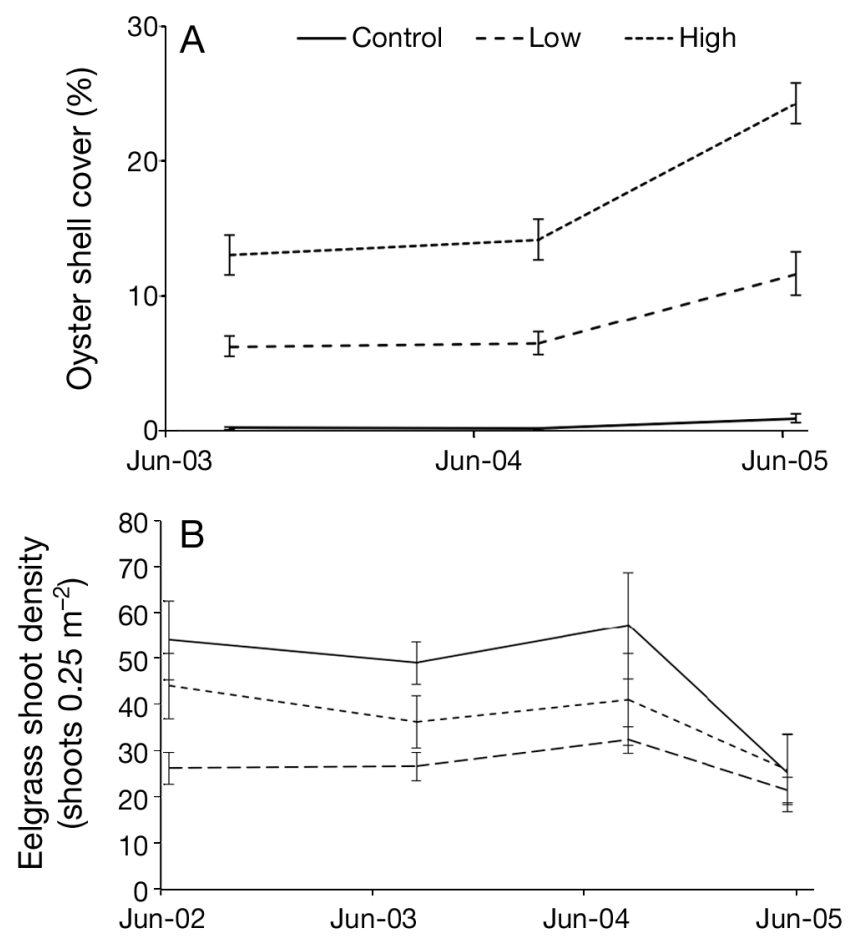

Fig. 5. Crassostrea gigas and Zostera marina abundance in the crop cycle experiment. (A) Percentage live C. gigas shell cover; (B) Z. marina shoot densities. June 2002, while not included in the analysis, is shown here for a pre-treatment comparison. Plots were replenished with oysters in April 2003 and April 2004. $\mathrm{N}=12$ per treatment. Error bars are $\pm \mathrm{SE}$

clarity. Other studies in the bay inferred substantial clearance by cultured oysters on tideflats (Banas et al. 2007), as well as strong control of eelgrass productivity by day length (Ruesink et al. 2010). Nevertheless, because intertidal eelgrass occurs in shallow water, any change in light penetration may be relatively unimportant, especially at the rather small scale of our experiments $\left(4 \mathrm{~m}^{2}\right)$.

We found that 1:1 tradeoffs in space occupancy do not describe the interactions between Crassostrea gigas and Zostera marina. One year after treatments were established in Expt 1, the decline in eelgrass shoot density exceeded the cover of oysters even at low oyster shell cover ( $\leq 5 \%$ ) (Fig. 4). The superior fit of the power-exponential versus reference models relating eelgrass density to oyster cover in Expt 1 in 2006 and 2007 corresponded to increasing thresholds of $12 \%$ and then $21 \%$ oyster shell cover, i.e. exponential declines in eelgrass shoot density when oyster cover exceeded 10 to $20 \%$. This experimental result corresponds to a negative interaction strength that changes with density; specifically, non-linear per capita effects of oysters that decrease dramatically above $20 \%$ oyster cover.
This $\sim 20 \%$ threshold after 3 yr was consistent with results from the crop cycle study (Expt 2), in which no statistically significant reduction in eelgrass density occurred. In years 1 and 2, there was a tendency for cultch-addition plots to have fewer eelgrass shoots than control plots, but mean values were not in the order expected from the 2 levels of oyster addition, and were more aligned with pretreatment densities. Thus, our results indicate that low densities of oysters can be compatible with eelgrass after a year or so, but that tradeoffs reliably occur both after initial establishment and above $20 \%$ oyster cover. Oyster cover $>50 \%$ is essentially impenetrable by eelgrass (Fig. 4). Current onground oyster culture practices in Willapa Bay typically result in oyster cover that starts below $20 \%$ (average $8 \%$, range $=5-20 \%$ cover and $10-40$ pieces of cultch $\mathrm{m}^{-2}$ ), and then oysters grow and cover increases (average 20\%, range $=5-35 \%$ cover), but cover can be $100 \%$ when oysters are left to form patchy reefs or hummocks, as occurs in the southern half of Willapa Bay (Dumbauld et al. 2006). Disturbances associated with bed maintenance and harvest may additionally reduce eelgrass density for a period of 2 to $4 \mathrm{yr}$ (Tallis et al. 2009). Within oyster aquaculture in Willapa Bay, the proportional area occupied by Zostera marina is similar to outside (Dumbauld et al. 2009), but the density and production per area may be 30 to $70 \%$ lower (Tallis et al. 2009).

Both eelgrass and oysters provide ecosystem services. Foundation species such as seagrasses are vital to coastal protection, provide refugia for commercially-important species, sequester carbon, and support nearshore food webs, primarily through detritus pathways as particulate organic carbon and dissolved organic matter (Barbier et al. 2011). Oysters similarly can protect shorelines from erosion (Piazza et al. 2005) and provide nursery habitat that could increase fishery production (Grabowski \& Peterson 2007).

The ecological consequences of eelgrass and oysters are likely to be location-specific and density dependent, and may differ where species are native versus non-native or wild versus cultured. Thus, a gap certainly remains between understanding species' distribution and the ecosystem services that they provide. Our results indicated disproportionately large tradeoffs between space occupants at high oyster density. Nevertheless, non-linearities in ecological functions, as well as some redundancies in function, may help reconcile competing demands (Barbier et al. 2008). 
Acknowledgements. This study was supported by the Western Regional Aquaculture Center through Grant No. 200338500-13198 from the United States Department of Agriculture, Cooperative State Research, Education, and Extension Service. J.L.R. and A.C.T. were funded by the Andrew W. Mellon Foundation. Washington Department of Fish and Wildlife provided field and laboratory space. Thanks to L. McCoy, B. Kauffman, and R. Hildenbrand for assistance in the field. E. Buhle receives our particular thanks for assistance in the field, helpful discussions, and comments on the manuscript.

\section{LITERATURE CITED}

Banas NS, Hickey BM, Newton JA, Ruesink JL (2007) Tidal exchange, bivalve grazing, and patterns of primary production in Willapa Bay, Washington, USA. Mar Ecol Prog Ser 341:123-139

Barbier EB, Koch EW, Silliman BR, Hacker SD and others (2008) Coastal ecosystem-based management with nonlinear ecological functions and values. Science 319: 321-323

Barbier E, Hacker SD, Kennedy C, Koch E, Silliman B, Stier AD (2011) The value of estuarine and coastal ecosystem services. Ecol Monogr 81:169-193

Beck MW, Brumbaugh RD, Airoldi L, Carranza A and others (2011) Oyster reefs at risk and recommendations for conservation, restoration, and management. BioScience 61: 107-116

> Booth DM, Heck KL Jr (2009) Effects of the American oyster Crassostrea virginica on growth rates of the seagrass Halodule wrightii. Mar Ecol Prog Ser 389:117-126

Borde AB, Thom RM, Rumrill S, Miller LM (2003) Geospatial habitat change analysis in Pacific Northwest coastal estuaries. Estuaries 26:1104-1116

Burnham KP, Anderson DR (2002) Model selection and multimodel inference: a practical information-theoretic approach. 2nd edn. Springer-Verlag, New York, NY

> Dumbauld BR, Booth SR, Cheney D, Suhrbier A, Beltran H (2006) An integrated pest management program for burrowing shrimp control in aquaculture. Aquaculture 261: 976-992

> Dumbauld BR, Ruesink JL, Rumrill SS (2009) The ecological role of bivalve shellfish aquaculture in the estuarine environment: a review with application to oyster and clam culture in West Coast (USA) estuaries. Aquaculture 290:196-223

> Dumbauld BR, Ruesink JL, Trimble AC, Kauffman BE (2011) The Willapa Bay oyster reserves in Washington State: fishery collapse, creating a sustainable replacement, and the potential for habitat conservation and restoration. J Shellfish Res 30:71-84

Grabowski J, Peterson CH (2007) Restoring oyster reefs to recover ecosystem services. In: Cuddington $\mathrm{K}$, Byers JE, Wilson W, Hastings A (eds) Ecosystem engineers: plants to protists. Academic Press, New York, NY, p 281-298

Gutierrez JL, Jones CG, Strayer DL, Iribarne OO (2003) Mollusks as ecosystem engineers: the role of shell production in aquatic habitats. Oikos 101:79-90

> Heck KL, Pennock JR, Valentine JF, Coen LD, Skelnar SA (2000) Effects of nutrient enrichment and small predator density on seagrass ecosystems: an experimental assessment. Limnol Oceanogr 45:1041-1057

Hickey BM, Banas NS (2003) Oceanography of the U.S.
Pacific Northwest coastal ocean and estuaries with applications to coastal ecology. Estuaries 26:1010-1031

Holmer M, Frederiksen MS, Mollegaard H (2005) Sulfur accumulation in eelgrass (Zostera marina) and effect of sulfur on eelgrass growth. Aquat Bot 81:367-379

Hughes AR, Bando KJ, Rodriguez LF, Williams SL (2004) Relative effects of grazers and nutrients on seagrasses: a meta-analysis approach. Mar Ecol Prog Ser 282:87-99

> Kelly JR, Volpe JP (2007) Native eelgrass (Zostera marina L.) survival and growth adjacent to non-native oysters (Crassostrea gigas Thunberg) in the Strait of Georgia, British Columbia. Bot Mar 50:143-150

> Koch EW, Barbier EB, Silliman BR, Reed DJ and others (2009) Non-linearity in ecosystem services: temporal and spatial variability in coastal protection. Front Ecol Environ $7: 29-37$

> Leoni V, Vela Z, Pasqualini V, Pergent-Martini C, Pergent G (2008) Effects of experimental reduction of light and nutrient enrichments ( $\mathrm{N}$ and $\mathrm{P}$ ) on seagrasses: a review. Aquat Conserv 18:202-220

Nelder JA, Mead R (1965) A simplex method for function minimization. Comput J 7:308-313

> Nelson KA, Leonard LA, Posey MH, Alphin TD, Mallin MA (2004) Using transplanted oyster (Crassostrea virginica) beds to improve water quality in small tidal creeks: a pilot study. J Exp Mar Biol Ecol 298:347-368

Nomura I (2009) The state of world fisheries and aquaculture 2008. FAO Fisheries, Rome

Peterson BJ, Heck KL Jr (2001a) An experimental test of the mechanism by which suspension feeding bivalves elevate seagrass productivity. Mar Ecol Prog Ser 218: $115-125$

> Peterson BJ, Heck KL Jr (2001b) Positive interactions between suspension-feeding bivalves and seagrass - a facultative mutualism. Mar Ecol Prog Ser 213:143-155

> Piazza BP, Banks PD, La Peyre MK (2005) The potential for created oyster shell reefs as a sustainable shoreline protection strategy in Louisiana. Restor Ecol 13:499-506

R Development Core Team (2009) R: A language and environment for statistical computing. $\mathrm{R}$ foundation for statistical computing, Vienna. www.R-project.org

Richardson NF, Ruesink JL, Naeem S, Hacker SD, Tallis HM, Dumbauld BR, Wisehart LM (2008) Bacterial abundance and aerobic microbial activity across natural and oyster aquaculture habitats during summer conditions in a northeastern Pacific estuary. Hydrobiologia 596:269-278

Ruesink JL, Lenihan HS, Trimble AC, Heiman KW, Micheli F, Byers JE, Kay MC (2005) Introduction of non-native oysters: ecosystem effects and restoration implications. Annu Rev Ecol Syst 36:643-689

Ruesink JL, Feist BE, Harvey CJ, Hong JS, Trimble AC, Wisehart LM (2006) Changes in productivity associated with four introduced species: ecosystem transformation of a 'pristine' estuary. Mar Ecol Prog Ser 311:203-215

> Ruesink JL, Hong JS, Wisehart L, Hacker SD, Dumbauld BR, Hessing-Lewis M, Trimble AC (2010) Congener comparison of native (Zostera marina) and introduced ( $Z$. japonica) eelgrass within a Pacific Northwest estuary. Biol Invasions 12:1773-1789

Schreffler D, Griffen K (2000) Ecological interactions among eelgrass, oysters, and burrowing shrimp in Tillamook Bay, Oregon. Report to the Tillamook County Performance Partnership. Tillamook County Performance Partnership, Garibaldi, OR

Short FT, Duarte CM (2001) Methods for the measurement 
of seagrass growth and production. In: Short FT, Coles RG (eds) Global seagrass methods. Elsevier, Amsterdam, p 155-182

Slawyck G, MacIsaac JJ (1972) Comparison of two automated ammonium methods in a region of coastal upwelling. Deep-Sea Res 19:521-524

Tallis HM, Ruesink JL, Dumbauld BR (2009) Oysters and aquaculture practices affect eelgrass density and productivity in a Pacific Northwest estuary. J Shellfish Res 28:251-261

Thom RM, Borde AB, Rumrill S, Woodruff DL, Williams GD, Southard JA, Sargeant SL (2003) Factors influencing spatial and annual variability in eelgrass (Zostera marina L.) meadows in Willapa Bay, Washington, and Coos Bay, Oregon, estuaries. Estuaries 26:1117-1129

Editorial responsibility: Kenneth Heck Jr., Dauphin Island, Alabama, USA
Vinther HF, Holmer M (2008) Experimental test of biodeposition and ammonium excretion from blue mussels (Mytilus edulis) on eelgrass (Zostera marina) performance. J Exp Mar Biol Ecol 364:72-79

Wall CC, Peterson BJ, Gobler CJ (2008) Facilitation of seagrass Zostera marina productivity by suspension-feeding bivalves. Mar Ecol Prog Ser 357:165-174

Waycott M, Duarte CM, Carruthers TJB, Orth RJ and others (2009) Accelerating loss of seagrasses across the globe threatens coastal ecosystems. Proc Natl Acad Sci USA 106:12377-12381

Wisehart LM, Dumbauld BR, Ruesink JL, Hacker SD (2007) Importance of eelgrass early life history stages in response to oyster aquaculture disturbance. Mar Ecol Prog Ser 344:71-80

Submitted: January 9, 2012; Accepted: July 20, 2012

Proofs received from author(s): October 27, 2012 